Vol. 4, No. 1, January 2016

Jurnal llmial

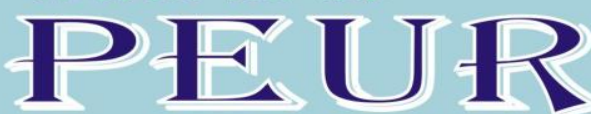

Media Kajian Ilmiah Sosial, Politik, Hukum, Agama dan Budaya
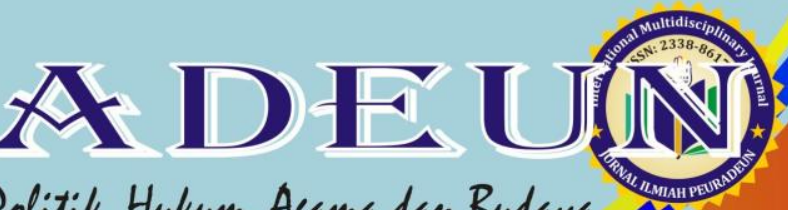


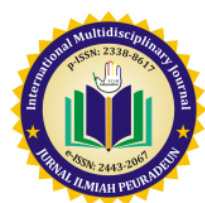

\title{
DINIYYAH IN PUBLIC SCHOOLS: A MODEL OF ISLAMIC CURRICULUM IMPLEMENTATION IN MULTI RELIGIOUS SOCIETY IN BANDA ACEH-INDONESIA
}

\author{
Marzuki \\ Islamic State University of Ar-Raniry, Banda Aceh-Indonesia \\ Email:marzukiabubakar84@gmail.com
}

Received: Sep 1, 2015

Accepted: Dec 7, 2015

Published: Jan 21, 2016

Article Url: https://journal.scadindependent.org/index.php/jipeuradeun/article/view/82

\begin{abstract}
The implementation of Islamic law in Aceh is included education by organizing Islamic curriculum in each level of education. How is the implementation of the curriculum in a multi-religious society like Banda Aceh? Banda Aceh has implemented a model of Islamic education through Diniyyah which has been implemented in all public schools in Banda Aceh since 2011, started with elementary, junior and senior high school. The results showed that the implementation of Islamic curriculum in Banda Aceh through diniyyah been operating effectively and do not make the non-Muslim communities disrupted. The implementation of Islamic education through Diniyyah did not clash with the main curriculum because it was implemented in the afternoon. So, this should be one of the models of Islamic curriculum implementation in Indonesia, particularly in areas which Muslim is majority without denying the existence of minorities.
\end{abstract}

Keywords: Diniyyah, Islamic Curriculum, Multi religious Society 


\section{A. Introduction}

Religious and cultural diversity in Indonesia has become one of the examples of inter-religious harmony in this world. Indonesia is a republic country which the majority of the population is Muslim. Islam which is growing in Indonesia is moderate Islam. It is very supportive toward religious and cultural diversity, so that the inter-religious harmony can be easily created in life. Although several time ago, the chaos in the name of religion for the benefit of specific groups or inter-religious conflict happened, but these cases can be mitigated and resolved by the government. Then the harmony still maintained well.

Aceh is the only province in Indonesia which has legalization from the government of Indonesia to implement Islamic law. The implementation of Islamic law is required for Muslims only, while non-Muslim community is only expected to respect the implementation of Islamic law in Aceh. So, since first time Islamic law implemented until now, there isn't inter-religious conflict happened in Aceh. Non-Muslim people are given freedom to practice their religion in Aceh. They can do all their activities safely and celebrate religious holidays respectively.

Banda Aceh is the capital of Aceh province which has a pluralistic society and religious diversity compared to other cities and areas in Aceh. In Banda Aceh, there are non-Muslim community from Catholic, Protestant, Hindu and Buddhist. They usually live in the center of Banda Aceh. NonMuslims are minority in Banda Aceh. However, they live in Muslim-majority society. The implementation of Islamic law in Aceh received a positive response from non-Muslim community in Banda Aceh. They are not disturbed, because Islamic law does not restrict them in social and economic life (Marzuki, 2010: 157-169).

Shari'a is the guidance of Islam in all aspects of life. The implementation of Shari'a was set in Aceh's local regulation No.5 of 2000 about the implementation of Shari'a (Dinas Syariat Islam, 2009: 257). The aspects of Shari'a's implementation are contained in Aceh's local regulation No.5 of 2000 about the implementation of Shari'a (Dinas syariat Islam, 2009: 257). Chapter IV, subsection 5, paragraph 2 is contained about Aqeedah, Worship, Muamalah, 
Morals, Education and Islamic missionary endeavor or enjoining to goodness and forbidding the evil, Treasury, Social, Symbols of Islam, Islamic defense, Qadha, Jinayat, Munakahat, and Mawaris (Dinas Syariat Islam, 2009: 260).

In educational aspect, the government of Banda Aceh has implemented Islamic curriculum for each level of education. The implementation of this curriculum is aimed to strengthen the youth and the children of Aceh to understand religious knowledge. Islamic educations which only have two hours of learning in national curriculum is not enough to make students understand the religious knowledge. However, the implementation of Islamic curriculum can not be separated from the presence of non-Muslims in schools, especially after the enactment of Aceh's education rules/Qanun (Serambi Indonesia, 2011: http://aceh.tribunnews.com). Therefore, the deepening of Islamic knowledge material is necessarily included in curriculum at all levels of education.

Based on this, it is interesting to be researched about the implementation of Islamic curriculum in Aceh and whether the implementation of it disrupts or not the learning process toward non-Muslim students.

\section{B. Islam and Multiculturalism}

In Islam, the presence of other faiths or non-Muslims is a reality (Faisal Ismail, 2012: 147-178). Islam has made a straight order to determine the relationship between Muslims and followers of other religions in Islamic societies. In Islamic view, all humans are descendants of the human family. Everyone has the right to live without exclusion and discrimination. Islam respects human being regardless of religion, gender, or skin color. It gives honor and protection to human rights. Because in view of the Qur'an, man glorified whatever the religion, color or gender (Al-Muzani, 2005: 9). Allah Almighty says:

"O you who have believed". Be persistently standing firm for Allah, witnesses in justice, and do not let the hatred of a people prevent you from being just. Be just; that is nearer to righteousness. And fear Allah; indeed, Allah is Acquainted with what you do"(al-Maidah [5]: 8).

Syihabudddin al-Qarafi, an ushul expert, (in Ibrahim ibn Muhammad al - Hamd al - Muzani: 2008) explained this verse, especially the meaning of "albirr", that Allah commanded Muslims toward non-Muslims' affairs, love the weak, fulfilling the needs of indigent, feeding the hungry, clothing to the naked people, give a soft-spoken to them gently and lovable, not to frighten and insult, 
to be patient toward the interference, praying for them to be given happiness, advising them in all affairs (both religious and other affairs), keeping away from gossiping them, keeping the property, family, honor, rights, and interest, helping them to reject injustice and give all their rights (al-Muzani, 2005: 11).

Scribes (non-Muslim) who lived in Muslim countries, they get tenure and special muamalah, they are "ahlu adh-zimmah". Prophet gave enormous attention to ahlu adh - zimmi. He said: "Remember, anyone who is oppressing people who are in agreement, reducing their rights, and assigned them more then their ability, or take something without any willingness in their heart, then I'm the one who will beat him on the day of judgment" (Abu Dawud).

Everyone has right to believe and worship, Included freedom which is guaranteed by Islamic law as the rights of non-Muslims. This is because Islam does not force them to enter into Islam, but gives freedom to people to choose. Non-Muslim rights are guaranteed. They are free to believe and worship in their own way as long as not disturbing Muslims. They are not despised, because everyone is free to practice their religion and sect without being forced to leave and change their religion. They are not pressured to move from their religion to Islam (al-Muzani, 2005: 39). It is based on the word of Allah: "There shall be no compulsion in (acceptance of) the religion. The right course has become clear from the wrong..." (Al-Baqarah [2]; 256).

In Medina Charter, paragraph 20 in the archive which was signed by various parties in the community of Medina, outlined that "Jews have a religion, Muslims also have a religion". Based on this charter, then the principle of religious freedom was set for non-Muslims (al-Muzani, 2005: 41).

The existence and interaction of Prophet Muhammad with Jews and Christians in Medina is a concrete example of how a Muslim should live among people of other faiths or multi religious society. However, Muslims are required to keep the boundaries, so they will not fall into heretical thinking. As Allah said in surah Al-kaafiruun verse 6 which means: ".....For you your religion and to me my religion".

\section{Islamic Education in Multi religious Communities in Banda Aceh}

The implementation of Islamic law gets priority from the government of Banda Aceh. The government is committed to implement Islamic law in all 
aspects of life. Education is one aspect which gets priority, especially education in school. The government fully supports the development of religion and public education institutions in Banda Aceh. For Islamic boarding school and other Islamic education institutions, the government continually helps their development, particularly in finance. Since the issues of deviant sect and its development in Indonesia, public educational institutions receive special attention from the government of Banda Aceh. The government sees it as a very dangerous threat to Muslims, especially younger generation. As known, there are only two hours of religious lesson in a week in public school. So, students only get introduction in religious lesson. It can not be denied, parents have obligatory to teach religious education to their children, either through recitation or inviting religious teacher to teach privately. However, school activities, extracurricular, and additional school tutoring lessons make students have lack of time to gain their knowledge in religious outside of school.

However, there are few public schools that brace them up to add religious lessons into 4 (four) hours. They add Quran and hadith lessons for 2 (two) hours after 2 (two) hours of religious lesson taught. But this is not enough to solve problems faced by public schools and certainly will make a discrimination against non-Muslims because additional religious lessons are included to main subjects. However, it will not be happened in schools in which the students are the majority of one religion.

Therefore, the government initiated a special program for public schools at primary school level (elementary), Junior high school (SMP), and Senior high school (SMA). The program is implemented in order to increase the school hours or opportunity for students to explore their religious knowledge. The program is called Diniyyah education program. The program is only implemented in Banda Aceh to be a model for other districts in Aceh and even Indonesia.

\section{Discussion}

\section{Diniyyah in Banda Aceh}

Diniyyah is derived from the word ad-din which means religion. So, Diniyyah education means religious education. Diniyyah in schools is one of solutions to transform students' learning character and to intensify them closer 
to Allah. This religious education is implemented in public schools. It is required from schools to hold this program in all levels. This program was initiated by the government since 2011 to provide more religious education which was only two hours in the national curriculum and was not in line with the implementation of Islamic law in Aceh. Besides aiming to stem the spread of deviant sects in Aceh, Diniyyah also aims to support the implementation of Islamic law in Aceh. By establishing beliefs and Shari'a for students, Diniyyah is very important to be implemented in public schools.

Diniyyah is one way to strengthen the aqidah younger generation. This will lead them to understand religion properly, so that Muslims will form outwardly and inwardly. Then students can fend deviant sects, because Banda Aceh was a fertile land for deviant sects. Through the diniyyah, the younger generation will not be easy to fall into the negative things and will have a noble character and strong faith foundation.

By the emergence of Diniyyah, it is expected to be a medium to improve affective intelligence both spiritually and socially. The curriculum 2013 itself is emphasizing on enhancing the affective intelligence both spiritually and socially. So that students will be able to understand and apply cognitive and psychomotor knowledge together with affective consciousness.

Diniyyah which is implemented in public schools conducted in the afternoon with four hours of allocation time in a week. The number of days in a week is various. For elementary school (SD) and junior high school (SMP), it is held two days in a week, while for senior high school (SMA) is only one day. The learning process is started at $2 \mathrm{pm}$ until $4 \mathrm{pm}$ for schools which hold Diniyyah only two days in a week. For schools which implement it once a week, the learning process is started at $2 \mathrm{pm}$ until $5.30 \mathrm{pm}$.

The government of Banda Aceh, recruits and contracts teachers for Diniyyah. The teachers get a monthly salary as well as Civil Servants (PNS). They are given a briefing before teaching in classrooms. The training are conducted to develop educators' skill in giving lessons to students, making good and bad decisions, taking good things and applying them in daily life. Trainings and briefings are provided to teachers to give them understanding and insight in making innovations during Diniyyah teaching process both methods and media. Methods are the paramount in achieving the learning objectives. 
The materials in Diniyyah are Islamic sciences like Fiqh, morals, monotheism knowledge and Quran. The materials taught are mostly from venerated books which used in Islamic schools in Aceh. Diniyyah uses practical approach in learning, especially in worshiping. For example, lesson of worship, after studying the theory then students practice it. It also happens to Quran. After studying the way to recite it by Tajweed from books, then students practice it in accordance with the science that has been studied. Beside religion materials, Diniyyah also aims to introduce students to understand the language of Jawi (Malay language written with Arabic letters). Because most ancient books used in Diniyyah are written in Malay language with Arabic font. It is expected that after following Diniyyah, students will be able to explore their own Islamic knowledge through books which are written in Arabic-Malay writing.

Started from 2014, the government of Banda Aceh requires prospective students in Junior high school and senior high school to attach a Diniyyah graduation certificate when registering to school. Diniyyah is compulsory program to be followed by students in Banda Aceh. A certificate will be obtained after graduating from Diniyyah in their previous school. Every student in Banda Aceh definitely has the certificate, and they have to attach it when they continue their studies to junior high school and senior high school. For those who come from outside Banda Aceh, they are required to take a test to obtain the certificate. Since 2014, the government through the Education Department issued a policy that primary school enrollment process is no longer required to have a certificate from Kindergarten (TK). (Serambi Indonesia, 2014: http:/ / aceh.tribunnews.com).

Diniyyah is not only as a complement to public education. But it has to be integrated together with the existing education system. The main orientation of Diniyyah is to deliver students to understand and able to practice Islamic knowledge, especially in practice of worshiping. The four hours time allotted for Diniyyah is still very little compared to materials that have to be mastered by students. However, the program has been successfully to fill the void or space for Islamic education in public schools.

\section{Islamic Curriculum and non-Muslims}

Curriculum is a matter has to be learned by every student in the learning process when taking an education process. Islamic curriculum is 
curriculum or subjects which contain Islamic sciences and taught to students. In Draft of Aceh's Qanun 2014 on the provision of education, chapter XI Article two (2) stated that the curriculum at public or Islamic schools in all types and levels of education are referred to things mentioned in paragraph (1) must contain the following subjects: (1) Main subjects: Aqidah, Fiqh, Quran and Hadith; (2) Morals and manners, (3) Civic education, and so on.

Seeing to the draft of Aceh's Qanun, the government of Aceh will implement Islamic curriculum and Aqeedah, Fiqh, Quran, Hadith, morals and manners as main subjects. These subjects at least represent Islamic curriculum. The implementation of Islamic curriculum is very important in order to support and align the development and implementation of Islamic law in Aceh. Islamic curriculum is a manifestation of the implementation of Islamic law in Aceh. So that implementation of Islamic law in Aceh will be realized in various aspects, including education. Then Islamic universal vision will be realized as Rahmatan lil 'alamaiin (mercy to the entire world). Therefore, it is very important to make a consideration on the model of the implementation of Islamic curriculum in public schools with a pluralistic society for the continuation of the implementation of Islamic law in Aceh .

The development of Aceh should be synchronized with the vision of the implementation of Islamic law in Aceh. Banda Aceh as one of the cities that have religious diversity very seriously undertakes the development and synchronizes it with the implementation of Islamic law in Aceh. The existence of non-Muslims as a minority community can be a challenge to implement a Shari'a-based development. However, this should not be a significant problem for the government of Banda Aceh in implementing the development. The development of the most important human resources is through education. Therefore, the government of Banda Aceh fully supports the provision of education in boarding schools, public schools and Islamic schools.

In education, the government provides equal opportunities for nonMuslims to study in any schools. However, Catholics and Protestants have their own schools under the foundation, Yayasan Methodits (Methodits Foundation) and Yayasan Budhi Dharma (Budhi Dharma Foundation). For those who want to continue their education to other public schools are also not restricted. However, since Muslims are the majority in Aceh, the religious lesson taught is 
Islam. For non Muslims are given freedom to choose between staying in classrooms or going out and not following the lesson, because the score for religious lesson will be given by their own religious leaders respectively.

Diniyyah can be an alternative to increase the duration of religious education in public schools. Then, Diniyyah also can be an alternative to avoid discrimination toward non-Muslim community, because Diniyyah is implemented separately from schools hours and reserved only for Muslims.

Therefore, the implementation of Diniyyah at public schools in Banda Aceh is one of alternatives for the implementation of Islamic curriculum in Aceh, so that these efforts need to be fully supported by the government and public in order to create harmony and peace in nation and state. The implementation of Diniyyah is also expected to stem the deviant sects and unknown religious understandings which enter to Aceh illegally and incompatible with Acehnese people.

\section{Diniyyah as a model of the implementation of Islamic curriculum in Multi religious community}

Diniyyah which is implemented by the government of Banda Aceh has become a model that can be used as a patent for Banda Aceh. It is able to replace the void space for Islamic knowledge to students. By this Diniyyah, the empty space has been filled. So, it can guarantee the existence of spiritual aspect and affective intelligence at students and not always idolizing cognitive and psychomotor intelligence.

Basically, Diniyyah has been implemented in informal education in Acehnese society, such as Balee (traditional place to learn Quran), (Ana Sofia, 2013: 33), Rangkang, Meunasah (M. Adli Abdullah, 2011: 149-153) and Dayah or Pesantren (Traditional Islamic Boarding School), (Marzuki, 2011: 221-234). However, these institutions have not been able to ensure all students will be able to follow and pursue the learning process as in Diniyyah. By the presence of Diniyyah in schools, it will ensure all students understand Islamic knowledge because it is formed in a formal format while Diniyyah in Acehnese society takes informal format. It is very rare for informal Diniyyah to have a well-ordered management. On the contrary, Diniyyah in schools is formed in formal format and can be interesting to students in learning Islamic knowledge. 
What has been done by the government of Banda Aceh is a very good achievement despite of many obstacles encountered in the implementation of Islamic curriculum in public schools in Banda Aceh. The implementation of Islamic curriculum by using Diniyyah can be one of implementation models of Islamic curriculum which is environmentally friendly not only in Banda Aceh but also in other cities. Although the program has not been commensurate with the goals of Islamic curriculum, but the content of Diniyyah is adequate for students to understand and practice Islamic knowledge, especially for daily worship, so that it can be adopted by other cities which also have pluralistic society.

\section{E. Conclusion.}

The government of Banda Aceh has embarked on a policy in order to implement Islamic curriculum in public schools that is by implementing Diniyyah. It is held in the afternoon with various of duration for each students, so that the program does not interfere non-Muslims. Non-Muslims can continue their education in public schools in Banda Aceh without any fear of discriminatory rules.

Diniyyah has become one of models for other cities in implementing Islamic curriculum in public schools. This model can be used as an alternative in realizing Islamic curriculum in Aceh without discriminating the rights of other faiths as minority. If it is successfully applied properly, then the implementation of Islamic law will not be a frightening specter. But it will show that Islam is truly a rahmatan lil'alamin (mercy to the entire world).

\section{Bibliography}

Abdullah, M. Adli (2011). Membedah Sejarah Aceh. Banda Aceh: Bandar Publishing. Al-Jamiah (2012). Paving the way for interreligious Dialogue, Tolerance, and Harmony: following Mukti Ali Path. Jurnal Al-Jamiah. 50 (1): 147-178.

al-Muzani, Ibrahim bin Muhammad al-Hamd (2005). Hidup Rukun Seperti Rasulullah SAW (at-Ta'mul ma'al Akharin), translated by Muzakkir A. S. and friends, first edition. Riyadh: National dialogue Center King Abdul Aziz Ryadh. 
Daily Newspapers, Serambi Indonesia. Monday, August 11, 2014.

Dinas Syari'at Islam (2009). Himpunan Undang-Undang, keutusan Presiden, Peraturan Daerah/Qanun, Instruksi Gubernur, Edaran Gubernur berkaitan Pelaksanaan Syari'at Islam. Banda Aceh: Dinas Syari'at Islam.

http:/ /aceh.tribunnews.com

http://indonesiaku.com

Karibi, R. A. I. N. (2015). Religion, Human Rights and the Challenges of Freedom. Jurnal Ilmiah Peuradeun, 3(1), 39-54.

Lvina, E. (2015). The Role of Cross-Cultural Communication Competence: Effective Transformational Leadership Across Cultures. Jurnal Ilmiah Peuradeun, 3(1), 1-18.

Marzuki. (2010). Kerukunan dan Kebebasan Beragama dalam Pelaksanaan Syariat Islam di Aceh, Jurnal Harmoni. 9 (36): 157-169. . (2011). Sejarah dan Perubahan Pesantren di Aceh. 11 (1): 221-234.

Qanun (Aceh's local regulation) No.5 of 2000 about the implementation of Shari'a.

Saminan, S. (2015). Internalisasi Budaya Sekolah Islami di Aceh. Jurnal Ilmiah Peuradeun, 3(1), 147-164.

Sofia, Ana (2013). Sistem Pendidikan Agama Islam dalam Masyarakat Aceh. Jurnal Finiqas: Jurnal Ilmu Keislaman dan Humaniora. 2 (1): 33.

Rajab, T. (2015). An Applied Model of Teaching Materials to Improve Students' Speaking Skill. Jurnal Ilmiah Peuradeun, 3(1), 103-118.

Yusoff, M. Z. M., \& Hamzah, A. (2015). Direction of Moral Education Teacher To Enrich Character Education. Jurnal Ilmiah Peuradeun, 3(1), 119-132.

ZA, T. (2014). Islamic Studies dalam Pendekatan Multidisipliner (Suatu Kajian Gradual Menuju Paradigma Global). Jurnal Ilmiah Peuradeun, 2(2), 211-234. 
